\title{
Accrediting Procedures with Special Reference to Libraries
}

Dr. Burns is secretary, Commission on Colleges and Universities, of the North Central Association of Colleges and Secondary Schools.

$\mathrm{T}_{\mathrm{t}}^{\mathrm{s}}$ o MANY college officials the North Central Association is just one more of the seemingly innumerable agencies, groups, and individuals asking for reports. What is your enrolment? What is your endowment income? How many books do you have in your library? What percentage of your income is from tuition? How many Ph.D's do you have on your faculty? These agencies, groups, and individuals ask for reports with complete disregard, so it seems, for the fact that filling them out takes time and costs money-time and money which the college official would much prefer to spend on developing some of his many ideas for strengthening the program of his institution.

Many of these requests for information come from researchers, students of education who need facts on which to base their studies. The administrator can pick and choose among such requests, basing his selection on the seeming merit of the request in relation to the amount of work required. But when it comes to the accrediting agencies, he does not have this free choice. He must comply with all requirements set down by such associations as a condition for maintaining the academic respectability

1 Paper presented at the meeting of the Junior College Libraries Section, A.C.R.L., Chicago, January 21, 1949. of his institution. Therefore he makes out all the reports required. It would not be so bad if these accrediting agencies stopped with reporting. "But," says the harried administrator, "they don't stop there. I assemble the data they want; they analyze it; measure the results by a yardstick of preconceived notions as to what a good institution should be. Then they inform me that the chosen company of the approved is not for my institution. I don't have enough books in the library, or my staff does not have enough persons holding the Ph.D."

This administrator, if he is sufficiently unorthodox, may wonder whether it may possibly not be more important that the library have the books required by the curriculum, that they be distributed in accordance with the relative emphasis placed on various elements in the curriculum, and that the students use the books, rather than that there be a certain number of books in the library. If he is a complete heretic, he may even raise a question as to whether possession of the Ph.D degree is the sine qua non of good teaching.

There is an even more serious consequence of this imposition of "standards" by outside agencies on which I should like to comment. One of the outstanding characteristics of American higher educationone of its greatest strengths-is institutional individuality. This individuality is preserved only to the extent that each institution is free to examine the needs of the 
particular clientele it wishes to serve, to define its functions in the light of that area of needs which it feels it can meet effectively, and then to set up a program and organization designed to attain the objectives which it has set for itself.

The accrediting agency which sets arbitrary minimum standards to which all institutions must conform tends to force all institutions into the same mold. To the extent that it enforces a set of minimum standards, it takes over the administration of the institution through limiting the freedom of the institution to plan its own affairs. This danger is so real that more than one eminent educator has called for an end to all accrediting, feeling that the evils of accrediting outweigh whatever benefits are to be derived.

The North Central Association attempts to avoid this danger. Fundamental to its purposes is the preservation of institutional initiative and individuality. I quote from the Statement of Policy Relative to the Accrediting of Institutions of Higher Education:

"In its accrediting procedures the Association intends, within the general patterns of higher education, to observe such principles as will preserve whatever desirable individual qualities member institutions may have. While it is necessary to emphasize certain characteristics that are recognized as basic, such as the competence of the faculty, the representative character of the curriculum, effective administration, standards of student accomplishment, and financial adequacy, it is regarded as of prime importance also to protect such institutional variations as appear to be educationally sound. Even in these basic matters it is clear that considerable divergence from average or optimum conditions may occur without perceptibly detracting from the essential educational worth of an institution. Uniformity in every detail of in- stitutional policies and practices is believed to be not only unnecessary but undesirable. Well conceived experiments aimed to improve educational processes are considered essential to the growth of higher institutions and will be encouraged."

It is clear, then, that in appraising the worth of an institution it is essential that one begin with the purposes of the institution and proceed from there to examine its program-the curriculum, the faculty, the student personnel services, the libraryin the light of the particular goals which the institution has set for itself. Implicit in this approach is the concept of a qualitative approach rather than reliance on merely quantitative measures. Quantitative measures are, to some extent it is true, used in the North Central accrediting procedures, but only where there is evidence that such quantitative measures are related to institutional quality. Furthermore, all the criteria employed are used not as separate and discrete measures, but are considered rather in relation first, to the purposes of the institution, and second, to all other characteristics of the institution. For example, one of the measures of faculty competence has to do with the extent to which the faculty holds graduate degrees, but no institution is refused North Central accreditation because the percentage of graduate degrees falls below a set minimum. Our concern is rather with the total pattern which an institution presents in the light of its professed objectives and in comparison with other institutions of the same general type. The number of graduate degrees is only one item in the total pattern, and may be expected to vary from one institution to another.

An accrediting agency, like any other social institution, must continually examine its purposes and procedures with a view to improvement; must be flexible enough to make the adjustments called for 
by changing conditions. Failure to do so may mean that the agency acts to exert a retarding influence on educational progress rather than as a constructive force lending its weight to educational improvement.

As one piece of evidence of North Central Association's awareness of this problem, I can point to the study of the junior or community college now underway under the sponsorship of the association. This institution is developing in response to social demands for an extension of educational opportunities on the post high school level and is assuming a place of growing importance in the American education scene. The association would be derelict in its responsibilities if it were to ignore, in connection with its accrediting activities, the unique character of this institution and were to continue to think solely in terms of the standard college and university. The study which is being carried on seeks to define the characteristics of the effective junior college and to develop appropriate criteria of excellence.

What I have said so far is by way of explanation of the North Central Association's general approach to the matter of accrediting. Let us see how these general principles are applied in the evaluation of the college library. First, I am glad to say that we do not ask how many volumes are in the library. Having made this statement with justifiable pride, I must then admit that we are not wholly satisfied with our evaluative techniques in the area of the library (or, for that matter, in other areas). I hope we never become completely satisfied. With complacency comes the end of progress.

Though the number of volumes is not a matter of importance we are, of course, concerned with the adequacy of the holdings. Under present procedures we attempt to get at this matter in several ways. For one thing, we are concerned with the ade- quacy of the holdings of standard works of general reference and special reference where pertinent to the curriculum of the institution. It is also obviously important that the library receive and make accessible the better general magazines, together with the standard periodicals in the fields included in the curriculum.

Checklists are employed for measuring the holdings of reference books and periodicals. These checklists were carefully constructed by a committee of librarians representing various types of institutions. But the checklist technique has, as you all know, serious weaknesses. In the first place, checklists get out of date very soon and practical considerations preclude as frequent revisions as would be necessary to keep them up-to-date. Then, too, since institutions are rated on the basis of the checklists, it is hardly surprising that they are sometimes used as buying guides. This not only destroys the value of the checklist as a measuring instrument, but-and this is even more serious-the institution is then buying the books it needs to secure a high rating rather than the books it needs for the institutional program.

Before proceeding further, I should report that our procedures for the evaluation of libraries are being re-examined by a representative committee of librarians, revised report forms are being prepared, and member institutions will be asked to make a report on their libraries next autumn. The checklist device will be subjected to particularly searching scrutiny, and may be abandoned. I cannot say what will be substituted for the checklists, should their use be discontinued. It may be found that expenditures for library purposes, for books, periodicals, visual aids, and other materials correlate highly with adequacy of holdings; if this were the case it would not be necessary to attempt to measure adequacy of holdings directly. 
Whether or not this turns out to be the case, it is clear that the level of expenditures is an important factor, since good intensions can hardly be realized unless funds are available for library purposes. Information is therefore secured on expenditures for books over a five year period and on library salaries.

Expenditures for library purposes and library holdings contribute only to the potential effectiveness of the library; they do not directly measure its actual effectiveness. The best of facilities, library or otherwise, are of little value unless they are used. Clearly, the effectiveness of a library is reflected in large part by the manner in which and the extent to which it is used by the students. This is, admittedly, a difficult matter to get at directly. I am sure you would agree that there is no statistical measure of student use which is wholly satisfactory.

It is also important in this connection that there be evidence of efforts to encourage student use ; sufficient copies of reserved books; direct access to books, such as open stacks, at least where the institution is small enough to permit easy supervision; special facilities for leisure reading; extension of library materials to student housing facilities; advertising of books for displays and notices.

The effective college library must of course serve the faculty as well as the students. Is provision made for supplying books and professional journals which will contribute to the professional growth of the faculty member even though they are too technical or specialized to be useful to most of the students? Does the librarian assume the responsibility for the preparation of lists of new and important publications for distribution among the teachers? Is regular provision made for informing teachers of the receipt of new publications? Are teachers permitted to withdraw and keep for a long period of time books which are not in demand by students? These are among the questions that are asked. Also of importance is the extent to which faculty members actually take advantage of the provisions made to facilitate their use of the library. Faculty use, like student use, is difficult to measure directly, but institutions are encouraged to keep records.

Let me return for a moment to the matter of holdings. As in other aspects of institutional appraisal, the North Central Association's concern is that the holdings reflect the purposes of the institution, and, since the library is important only in relation to the total institutional pattern, that the holdings be appropriate to the curriculums offered and the courses taught. Clearly, an institution should have the most complete collection possible of library materials in those fields in which it has the most students studying. A large collection of materials relating to subjects not considered in the courses offered is not regarded as contributory to the effectiveness of the library. In setting up the budget, funds should be allocated in terms of some systematic procedure for determining the relative needs of the various areas.

I have tried to set forth briefly the general point of view underlying the North Central Association's accrediting procedures and to indicate the kinds of things we look at in appraising the library. As you can see, there are weaknesses in these procedures, and there are also omissions-for example, there is no reference in the present statement of criteria to audio-visual materials. As conditions change in the world of education we must re-examine our procedures and do what we can to remedy the deficiencies. But if the general principles of accrediting under which we operate are sound-and I believe they are-the association can be a constructive force for the improvement of educational practice. 